\title{
Clinical and Functional Significance of Accessory Brachialis Muscle: An Unique Anatomical Variant
}

\author{
Significado Clínico y Funcional del Músculo Braquial Accesorio: Una Variante Anatómica Única
}

\author{
Sreenivasa Rao Sirisinagandla* \& Bhagath Kumar Potu**
}

SIRASANAGANDLA, S. R. \& POTU, B. K. Clinical and functional significance of accessory brachialis muscle: A unique anatomical variant. Int. J. Morphol., 31(4):1383-1385, 2013.

SUMMARY: A thorough knowledge of the variations in the patterns of muscle insertion and the consequent neurovascular entrapment due to them is important for orthopedic and plastic surgeons. During routine dissection, we encountered a unique occurrence of an accessory brachialis muscle ( $\mathrm{acBr}$ ) blending with the medial aspect of bicipital aponeurosis in the cubital fossa. It also entrapped the median nerve and brachial artery due to its superficial position. The abnormality reported here might result in neurovascular compression symptoms in the upper limb and possible mechanical advantages or disadvantage in the flexion of elbow joint. To the best of our knowledge, the brachialis variant insertion we present here is rare in the list of its anomalies. We also discuss in this report the embryological background and the clinical application of the variation that can abet clinicians in evaluating symptoms involving the upper limb.

KEY WORDS: Accessory brachialis; Variation; Neurovascular compression.

\section{INTRODUCCIÓN}

The brachialis muscle lies underneath the biceps brachii and arises from the anteromedial and anterolateral surfaces of the lower half of the shaft of humerus. A few fibers take origin from the lower part of the spiral groove and medial intermuscular septum too. This broad muscle covers the anterior part of elbow joint and converges to form a flat tendon, which is inserted into the anterior surface of coronoid process and tuberosity of ulna. The medial and major bulk of the muscle supplied by the musculocutaneous nerve and the small lateral portion by the radial nerve. Brachialis flexes the elbow joint. The brachial artery begins as a continuation of the axillary artery and is superficial throughout its course in the arm. When it enters the cubital fossa it lies anterior to brachialis and lateral to median nerve. At the cubital fossa it is crossed by the bicipital aponeurosis which separates the artery from the median cubital vein (Williams et al., 2005).

The most frequent variants of brachialis muscle consist of its subdivision into two or more parts, and distal insertions being irregular and variable. The parts may be attached to the coronoid process of the ulna, radius on or below the tuberosity, fascia of the forearm (brachiofascialis of Wood), or muscles of the forearm arising from the medial epicondyle (Bergman et al., 2000).
We report a case of possible entrapment of the median nerve and brachial artery due to additional fasciculi of brachialis muscle, which formed an abnormal fibro muscular tunnel above the cubital fossa. Hypertrophy of the muscle fibers related to excessive use is an important factor in the development of isolated vascular, neural, or combined neurovascular lesions (Vadgaonkar et al., 2008).

\section{CASE REPORT}

During routine dissections a 45-year-old male cadaver presented a rare variation in the anterior compartment of the $\mathrm{arm}$. The variation was found in the left limb and was unilateral (Fig. 1). From the distal third of brachialis muscle a few fleshy fibers descended downwards and medially in the form of a belly with the tendon crossing the cubital fossa contents and blended with the medial aspect of bicipital aponeurosis and on close observation we found that it was attached on the sub cutaneous posterior margin of ulna. The median nerve and brachial artery were seen passing deep to the accessory slip of brachialis. Rest of their course and relations were normal. The tendon crossing the median nerve and brachial artery was, measured $6 \mathrm{~cm}$ in length and $0.6 \mathrm{~cm}$ in width.

* Department of Anatomy, Melaka Manipal Medical College, Manipal University, Manipal, India.

**. Department of Anatomy, College of Medicine and Medical Sciences, Arabian Gulf University, Kingdom of Bahrain. 


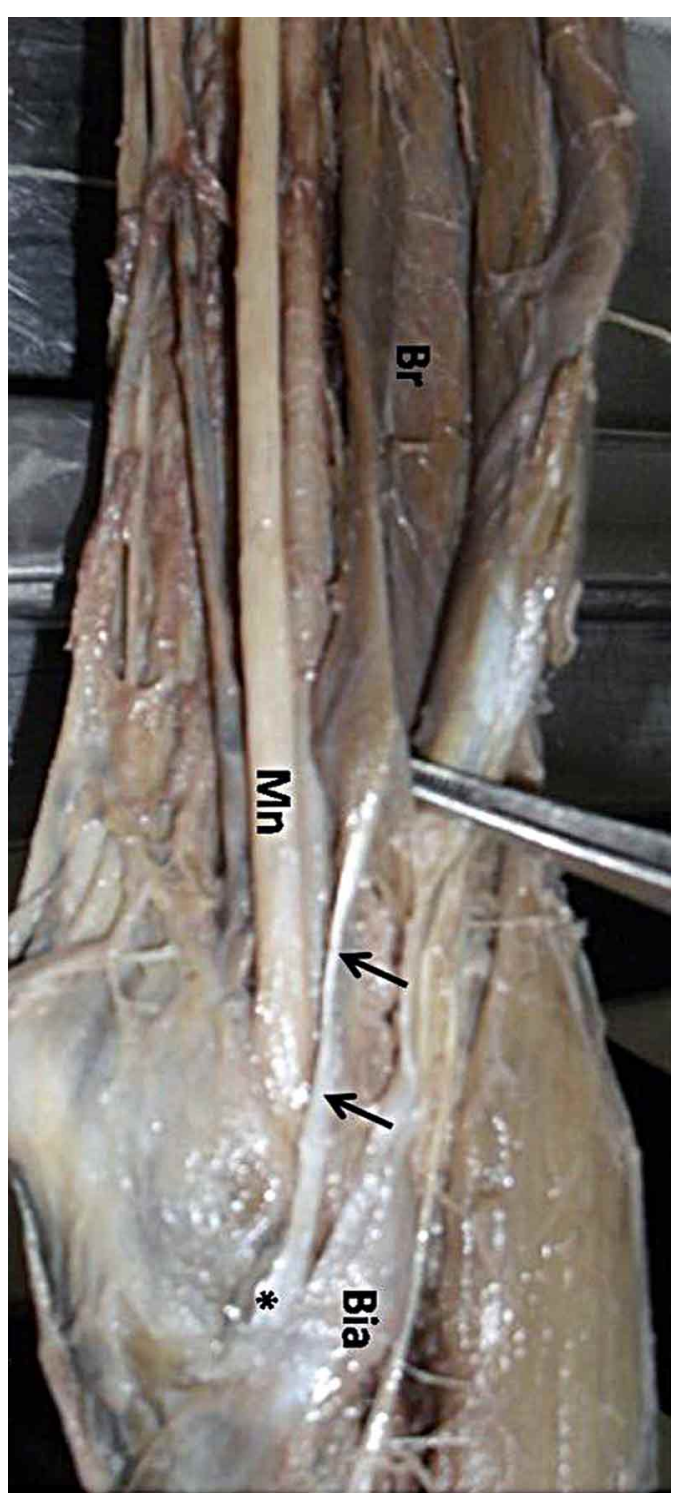

Fig. 1. Dissection of the left upper limb showing the accessory brachialis tendon and course of the median nerve and brachial artery underneath it. (Mn: median nerve; Br: brachialis muscle fibres ; Bia: bicipital aponeurosis and * showing the blending of accessory brachialis tendon with bicipital aponeurosis, arrow showing the accessory brachialis tendon.

\section{DISCUSSION}

Variations in the origin and insertion of the brachialis are rare; however, there are a lot of reports on variations of the brachial artery and the median nerve. Vadgaonkar et al. reported a case of an acBr that crossed both the brachial artery, the median nerve and united with the fibers of pronator teres muscle from radial side. George \& Nayak (2008), found a case of an acBr that merged with the superficial flexors of the forearm and partly inserted to the olecranon process. Loukas M et al. (2006), published a case of an $\mathrm{acBr}$ that took origin from mid shaft of humerus and the medial intermuscular septum.

In the present case, we have considered $\mathrm{acBr}$ as a different muscle entirely due to its distinctly separate insertion from those of brachialis muscle itself. The acBr arose proximally from the medial aspect of the brachialis muscle in the lower anterior region of arm and distally, was attached on to the bicipital aponeurosis. Due to the above attachment, the acBr muscle will contract in both supination and flexion. This may predispose to entrapment syndromes, as the above variation may bring compression of the median nerve due to contraction of acBr during the movement of the forearm. Embryologically, the precursor of musculoskeletal lineage is derived from the myotome of the somites. Cells in the proximal limb bud secrete several growth factors that stimulate the myoblasts to migrate into the developing limb buds. These pre-muscle cells express adhesion molecules that are important for the proper distributing of muscles throughout the limb (Carlson, 2004).

Loukas et al., opined that occurrence of an acBr might indicate alterations in the formation and structure of the myotome or somite. Functionally, the additional slip that we have noted may mechanically stabilize the ulnohumeral joint and may be used to reconstruct the annular ligament or the medial collateral ligament of the elbow joint (George \& Nayak).

\section{CONCLUSION}

Compression of the median nerve and brachial artery by many anatomical variants and their role in carpal tunnel syndrome, pronator teres syndrome and anterior interosseous syndrome was well described in the past by various authors (Wadhwa et al., 2004; El-Naggar \& Al-Saggaf, 2004; Nakatani et al., 1998; Seitz et al., 2007). Clinicians, in their consideration of differential diagnosis of tumors in the brachium by advanced radiological examination, should not forget the presence of supernumerary or aberrant fascicules like the one described in this case.

SIRASANAGANDLA, S. R. \& POTU, B. K. Significado clínico y funcional del músculo braquial accesorio: Una variante anatómica única. Int. J. Morphol., 31(4):1383-1385, 2013.

RESUMEN: Es importante para los cirujanos ortopédicos y plásticos, el conocimiento integral de las variaciones en los patrones de inserción de los músculos y el consiguiente atrapamiento neurovascular. Durante una disección de rutina, encontramos un caso único de un músculo accesorio braquial con aponeurosis bicipital en el lado medial de la fosa cubital. También cubre la arteria braquial y nervio mediano debido a su posición superficial. La anomalía informada aquí podría resultar en síntomas de compresión neurovascular en el miembro superior y las posibles ventajas o desventajas mecánicas de flexión de 
la articulación del codo. De acuerdo a lo estudiado, la inserción variante braquial que presentamos aquí es un caso raro dentro de la lista de sus variaciones. También se discuten en este informe la base embriológica y la aplicación clínica de la variación que puede ser útil para los clínicos en la evaluación de los síntomas relacionados con el miembro superior.

PALABRAS CLAVE: Accesorios Braquiales ; Variación ; Compresión neurovascular.

\author{
Correspondence to: \\ Dr. Bhagath Kumar Potu, Ph.D \\ Department of Anatomy \\ College of Medicine and Medical Sciences \\ Arabian Gulf University \\ P.O. Box 26671 \\ KINGDOM OF BAHRAIN
}

Email: potu_kumar2000@yahoo.co.in

Received: 06-06-2012

Accepted: 24-08-2013
Bergman, R. A.; Afifi, A. K. \& Miyauchi, R. Part I: Muscular System. In: Bergman, R. A.; Afifi, A. K. \& Miyauchi, R. Illustrated encyclopedia of human anatomic variation, 2000. Available in: http://www.anatomyatlases.org/ AnatomicVariants/AnatomyHP.shtml

Carlson, B. M. Human embryology and developmental biology. 3rd ed. Mosby, St. Louis, 2004. pp.224-5.

El-Naggar, M. M. \& Al-Saggaf, S. Variant of the coracobrachialis muscle with a tunnel for the median nerve and brachial artery. Clin. Anat., 17(2):139-43, 2004.

George, B. M. \& Nayak, S. B. Median nerve and brachial artery entrapment in the abnormal brachialis muscle - a case report. Int. J. Anat. Var., 7:41-2, 2008.

Loukas, M.; Louis, R. G. Jr.; South, G.; Alsheik, E. \& Christopherson, C. A case of an accessory brachialis muscle. Clin. Anat., 19(6):550-3, 2006.

Nakatani, T.; Tanaka, S. \& Mizukami, S. Bilateral four-headed biceps brachii muscles: the median nerve and brachial artery passing through a tunnel formed by a muscle slip from the accessory head. Clin. Anat., 11(3):209-12, 1998.

Seitz, W. H. Jr.; Matsuoka, H.; McAdoo, J.; Sherman, G. \& Stickney, D. P. Acute compression of the median nerve at the elbow by the lacertus fibrosus. J. Shoulder Elbow Surg., 16(1):91-4, 2007.

Vadgaonkar, R.; Rai, R.; Ranade, A. V.; Nayak, S. R.; Pai, M. M. \& Lakshmi, R. A case report on accessory brachialis muscle. Rom. J. Morphol. Embryol., 49(4):581-3, 2008.

Wadhwa, S.; Mehra, S.; Khan, R. Q. \& Kapur, V. Abnormal musculoaponeurotic tunnel in the arm: possible entrapment of the median nerve and brachial artery with high origin of nerve to pronator teres within tunnel. Clin. Anat., 17(4):360-3, 2004.

Williams, P. L.; Bannister, L. H.; Berry, M. M.; Collins, P.; Dyson, M.; Dussek, J. E. \& Ferguson, M. W. J. Gray's Anatomy. $38^{\text {th }}$ ed. Edinburgh, Churchill Livingstone, 2005. pp.843-4. 